\title{
One-Step Endovascular Treatment of Bilateral Traumatic Carotid-Cavernous Fistulae with Atypical Clinical Course
}

\section{Atipik Klinik Seyirli Bilateral Travmatik Karotid Kavernöz Fistülün Tek Basamakl Endovaskïler Tedavisi}

\author{
Alexandru CHIRIAC ${ }^{1,2^{*}}$, Bogdan F. ILIESCU ${ }^{1^{*}}$, Nicolae DOBRIN ${ }^{1}$, Ion POEATA ${ }^{1,2}$ \\ 1"Prof. Dr. N. Oblu" Clinical Emergency Hospital Iasi, Romania \\ 2 "Gr. T. Popa" University of Medicine and Pharmacy Iasi, Romania \\ "These authors contributed equally to this paper. \\ Corresponding Author: Bogdan F. ILIESCU / E-mail: bogdan.iliescu@gmail.com
}

\begin{abstract}
Traumatic carotid-cavernous fistula (TCCF) is a rare neurovascular pathologic entity. The bilateral form occurs even rarer and given the potential risk for both optic tracts presents an urgent indication for quick and effective treatment. We present a patient with a bilateral Barrow type A TCCF with a fulminant development of symptoms, who was successfully treated with bilateral detachable balloons in a single session endovascular procedure. The patient experienced complete relief of symptoms, however the complete neurological deficit in the left optic nerve was persistent.
\end{abstract}

KEYWORDS: Traumatic carotid-cavernous fistulae, Endovascular, Treatment, Balloon

öz

Travmatik karotid kavernöz fistül (TKKF) nadir bir nörovasküler patolojik bozukluktur. Bilateral tip daha da nadirdir ve her iki optik TRAKTUS için olası risk nedeniyle hızlı ve etkin tedavi açısından acil bir endikasyon mevcuttur. Belirtileri fulminan gelişen ve tek seanslı endovasküler bir işlemde bilateral ayrılabilir balonlarla başarılı şekilde tedavi edilmiş bir Bilateral Barrow tip A TKKF hastasını sunuyoruz. Hastanın belirtileri tamamen geçti ancak sol optik sinirdeki tam nörolojik kusur devam etti.

ANAHTAR SÖZCÜKLER: Travmatik karotid kavernöz fistül, Endovasküler, Tedavi, Balon

\section{INTRODUCTION}

Traumatic carotid-cavernous fistula (TCCF) is a high-flow communication between the internal carotid artery and the cavernous sinus. Depending on the size and venous drainage, it may cause neuro-ophthalmologic symptoms, cranial nerve palsy, or cerebral hemorrhage. TCCF is usually single and unilateral, and unilateral double TCCFs and bilateral TCCFs are uncommon $(8,12,13)$. Herein, we report the case of a patient with a prior mild brain trauma that developed in a very short interval a bilateral TCCF with an accelerated, severe clinical course.

\section{CASE REPORT}

A 57-year-old woman was involved one week before presentation in a relatively low impact accident (she was hit by a bicycle) which caused a loss of consciousness for ten minutes. She presented at the ambulatory consultation room complaining of a mild and episodic headache since the accident. The neurological exam was normal at the time of presentation. A CT-scan was performed and showed an area of cerebral contusion in the left temporal lobe (Figure $1 \mathrm{~A}-\mathrm{C})$. A decision was made to admit her and keep her under observation for a couple of days. After admission, the evolution was good for the first four days, with steady improvement of the headaches that became more rare and of a milder intensity. Suddenly, in the evening of the fifth day she started to develop left eye exophthalmos, the headache worsened progressively, and the patient became confused. Within a couple of hours, the left exophthalmos became severe, with significant chemosis and intense eyelid edema, preceded by proptosis and loss of vision in the same eye, while the right eye started developing exophthalmos of a lesser amplitude. The physical exam confirmed pulsating exophthalmos and ocular bruit especially in the left eye (Figure 1D). Her consciousness level deteriorated rapidly to a GCS of 9 .

Having a relatively clear clinical diagnosis, catheter angiography was performed in emergency and it confirmed the presence of bilateral large TCCFs, draining bilaterally into the ophthalmic veins, inferior petrosal sinuses, left sylvian 

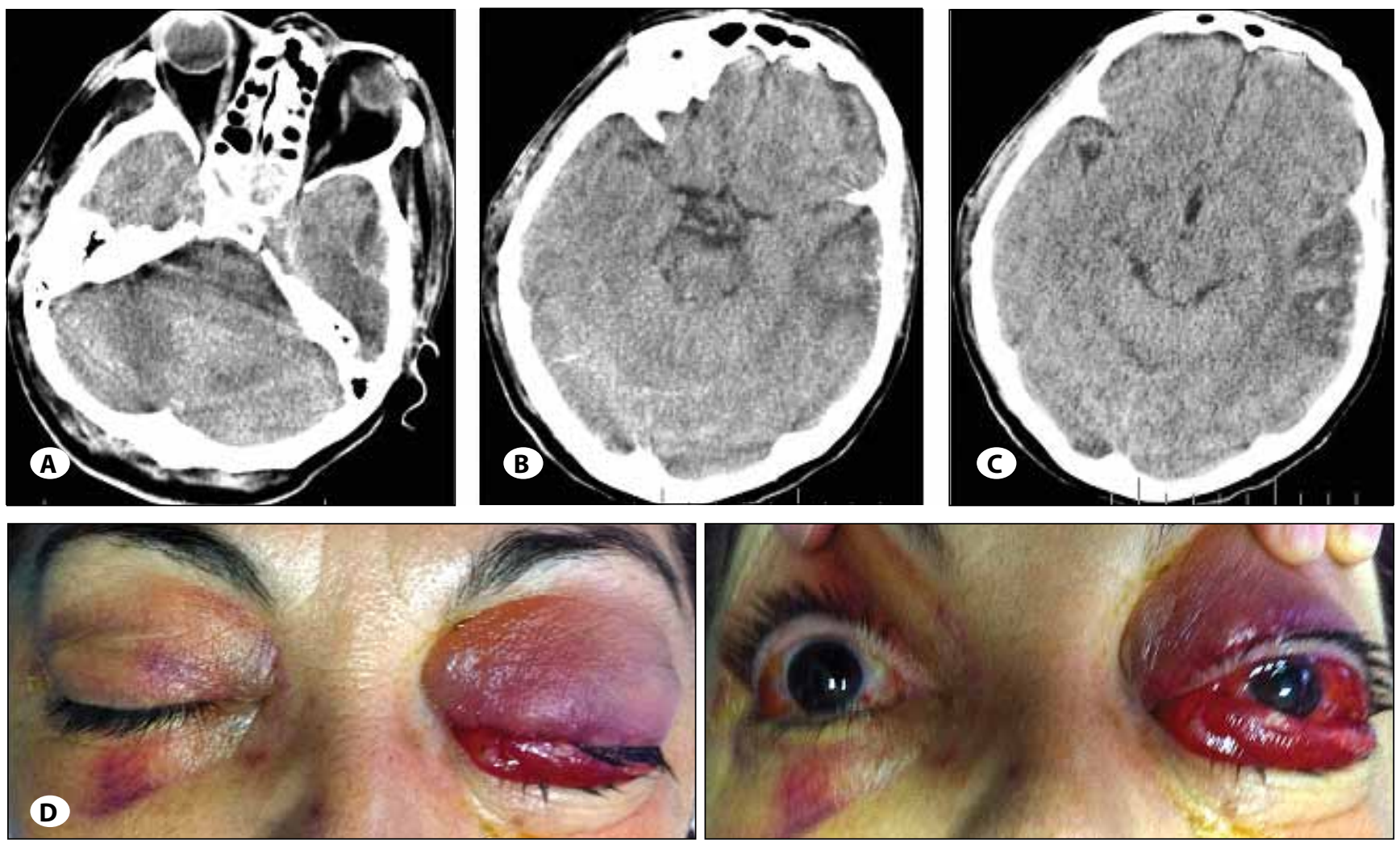

Figure 1: A-C) Ct scan aspect at admission depicting the left temporal cerebral contusion area and discrete signs of subarachnoid hemorrhage. D) Patient aspect one hour after clinical onset of the fistulae.

vein, and left petrosal vein (Figure 2A, B). The endovascular team decided to solve both fistulae in the same session, given the clinical aggressiveness due especially to the left fistula.

The line of management was decided taking into consideration the feasibility of an endovascular approach with detachable balloon occlusion. The endovascular procedure was performed under general anesthesia. Percutaneous access was obtained via the right femoral artery using a 7-French sized vascular introducer sheath (Balton Ltd.). A 7F guiding catheter (JR 3.5-Cordis) was placed in the right cervical ICA over a $0.035^{\prime \prime}$ heparin coated guidewire at approximately the second cervical vertebral body level. For prevention of thrombus formation on the catheter and balloon systems a 5 000Ul heparin were administrated intravenously.

After cavernous sinus measurements on angiography images we decided to use a GOLDBAL $2(19 \times 11 \mathrm{~mm}$ when fully expanded $60 \mathrm{ml} /$ BALT) detachable balloon for fistulae occlusion. The balloon is manually attached to a flowdependent microcatheter with progressive suppleness for detachable balloons (1.8-French (red-tip) and outer -2.4 French (green) (Magic-MABDTE). The entire system was passed through the guiding catheter. The space between the microcatheter and the guiding catheter was perfused with pressurized normal saline to prevent thrombus formation. The balloon attached to microcatheter was advanced through the guiding catheter under fluoroscopic guidance into the fistula site. A diluted contrast agent was used to inflate the balloon. When the balloon was inflated in what appeared to be the correct position, a diagnostic angiogram was performed through the guiding catheter to ensure that the fistula was completely occluded, and that the ICA was still patent. The balloon was detached simply by traction of delivery microcatheter.

After the procedure, the patient was given $100 \mathrm{mg}$ aspirin and $75 \mathrm{mg}$ clopidogrel daily via nasogastric tube starting immediately, and was maintained at normotensive blood pressure in the intensive care unit. The patient recovered the consciousness level, and the left exophthalmos, periorbital bruit and ophthalmic manifestations disappeared immediately after the procedure. However, proptosis and the loss of vision didn't recover (Figure 3A, B). The followup angiography, performed two days after the procedure showed the correct placement of the balloons and the complete occlusion of the fistulae (Figure 3C, D). The patient was transferred to a rehabilitation hospital after another week spent in our clinic with a last simple radiograph control (Figure 3E).

The follow-up consisted of an ambulatory visit, one month after the procedure, which documented complete recovery of the right eye, slightly recovered proptosis, and complete loss of vision in the left eye (Figure 4A). At six months the patient was admitted for a day and a control angiography 

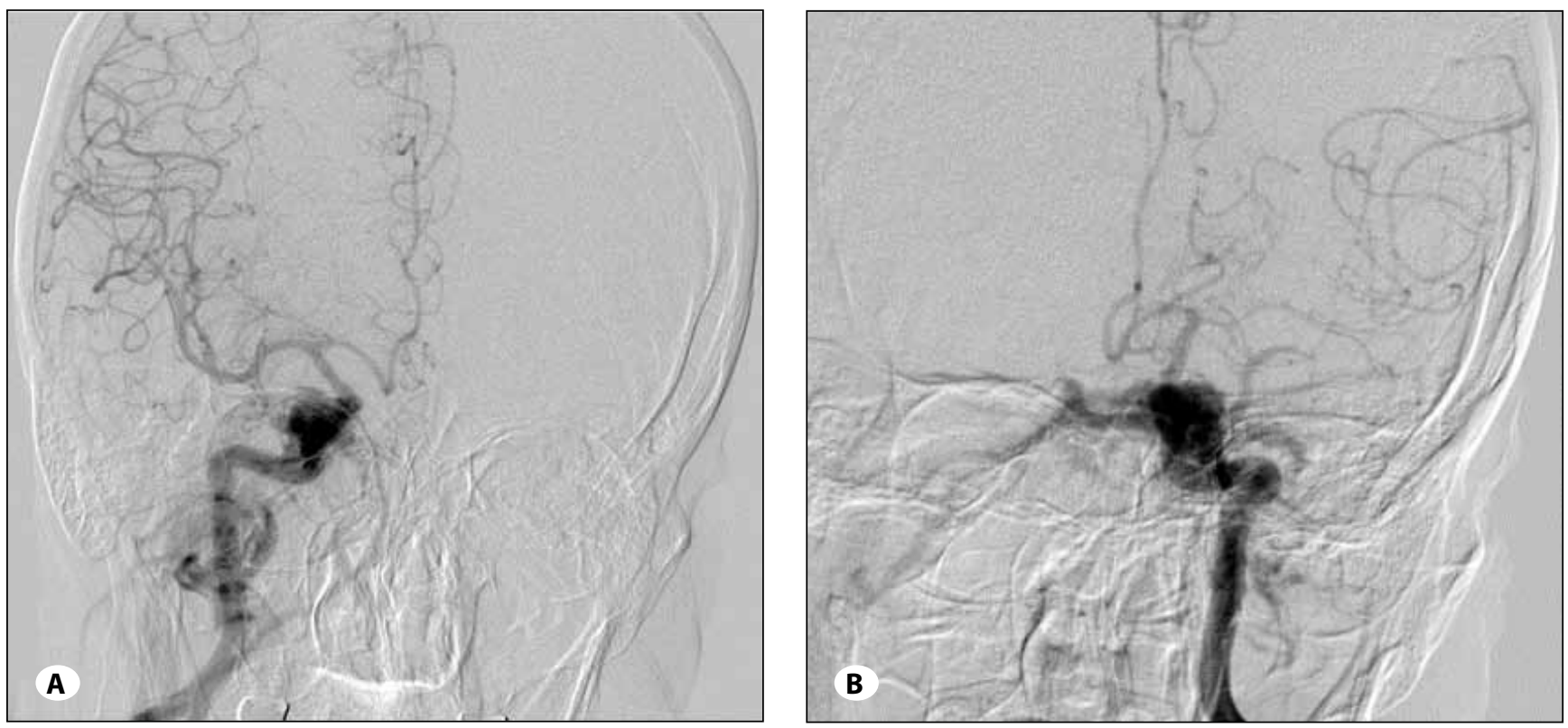

Figure 2: Angiographic appearance of right (A) and left (B) carotid cavernous fistulae.
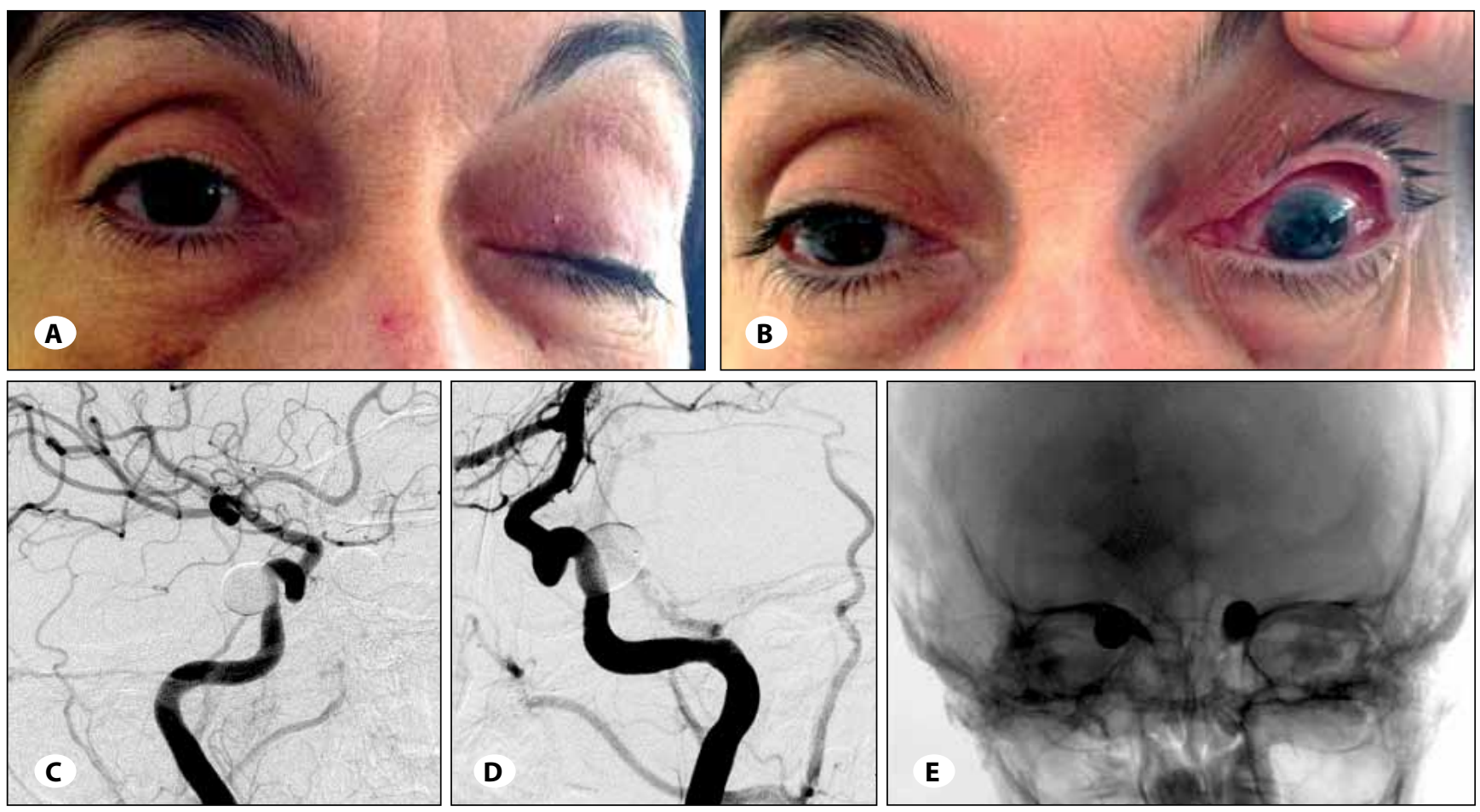

Figure 3: A,B) Patient aspect two days after the endovascular procedure showing the remission of the vascular related signs with the persistence of left oculomotor paresis. Angiographic appearance of the balloons placed in the $\mathbf{C}$ ) right and D) left cavernous sinuses at the control angiography performed two day after the embolization session. E) Radiographic appearance of the balloons one week post-embolization at discharge.

was performed, which showed complete occlusion of both fistulae and the expected reduction in size of the intra-arterial balloons (Figure 4B, C). Neurologically, the patient showed an important improvement in left eye movement.

\section{DISCUSSION}

We report the successful occlusion of a bilateral direct TCCF (Barrow type A) with a rapid evolution of critical neurologic symptoms performed in one session. It is estimated that incidence of TCCF is $0.17-1.01 \%$ after head injury. It is usually 

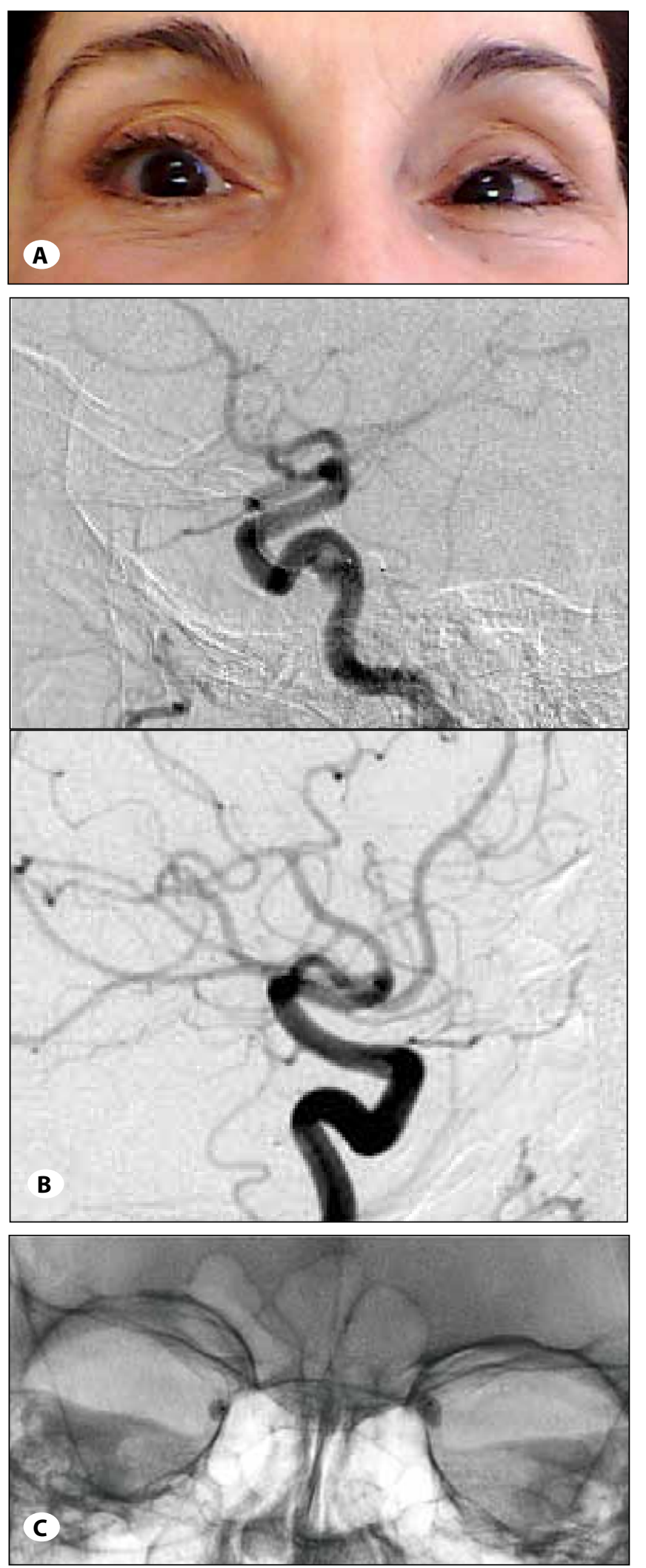

Figure 4: A) Patient aspect one month after the embolization. It showed a moderate recovery of left oculomotor function. B) Angiographic and $\mathbf{C}$ ) radiographic appearance of the balloons six months after the endovascular procedure. unilateral, but bilateral TCCFs have been reported in the literature rarely $(6,12)$. The average time between trauma and embolization for the patients of one series was 94.0-108.4 days (17). In our case two distinct clinical aspects draw attention. First, the trauma was fairly mild with minimal brain lesion. Second, the clinical picture of carotid cavernous fistula had a very accelerated pace, the full array of symptoms becoming intensely manifest over a time-span of couple of hours. The neurological deficit in terms of oculomotor nerve palsy and visual deficit in the left eye installed from the beginning and preceded the periorbital signs of venous stasis.

For treatment of TCCF, detachable balloons have been widely used. In this case, bilateral TCCFs were treated simultaneously using this technique, while the ICA flow was preserved on both sides. Although recent studies have indicated an advantage of using the detachable coils in the treatment of the fistulas we used balloons because they were readily available and allowed an immediate and easy intervention. The procedure was facilitated by the fact that fistula anatomy on both sides was appropriate for this technique. It has been noted that technical difficulties are not uncommon and are related to the size of the fistula and the cavernous sinus. The fistula should be smaller than an inflated balloon but large enough to allow passage of a deflated or partially inflated balloon, and the CS should be large enough to accommodate an inflated balloon or balloons.

Mentioned as one of the significant neurological complications of detachable balloon treatment, the oculomotor palsy was unaffected by the procedure. It had improved slightly at the 6-month follow-up.

\section{CONCLUSIONS}

Most of bilateral TCCF cases are associated with severe neurological symptoms. The fulminant nature of symptoms development and evolution require an immediate and optimal treatment. A single session endovascular treatment using detachable balloons is still an effective therapeutic option especially in high-flow type CCF and should be considered as a viable and safe procedure in these rare cases.

\section{REFERENCES}

1. Barrow DL, Spector RH, Braun IF, Landman JA, Tindall SC, Tindall GT: Classification and treatment of spontaneous carotid-cavernous sinus fistulas. J Neurosurg 62:248-256, 1985

2. Cho KC, Seo DH, Choe IS, Park SC: Cerebral hemorrhage after endovascular treatment of bilateral traumatic carotid cavernous fistulae with covered stents. J Korean Neurosurg Soc 50(2):126-129, 2011

3. Cognard C, Januel AC, Silva NA Jr, Tall P: Endovascular treatment of intracranial dural arteriovenous fistulas with cortical venous drainage: New management using Onyx. AJNR Am J Neuroradiol 29:235-241, 2008

4. Debrun G, Lacour P, Vinuela F, Fox A, Drake CG, Caron JP: Treatment of 54 traumatic carotid-cavernous fistulas. J Neurosurg 55:678-692, 1981 
5. Elhammady MS, Wolfe SQ, Farhat H, Moftakhar R, Aziz-Sultan MA: Onyx embolization of carotid-cavernous fistulas. J Neurosurg 112: 589-694, 2010

6. Fabian TS, Woody JD, Ciraulo DL, Lett ED, Phlegar RF, Barker DE, Burns RP: Posttraumatic carotid cavernous fistula: Frequency analysis of signs, symptoms, and disability outcomes after angiographic embolization. J Trauma 47: 275-281, 1999

7. Graeb DA, Robertson WD, Lapointe JS, Nugent RA: Avoiding intraarterial balloon detachment in the treatment of posttraumatic carotid-cavernous fistulae with detachable balloons. AJNR Am J Neuroradiol 6: 602-605, 1985

8. Graziussi G, Granata F, Terracciano S: Bilateral carotidcavernous fistula of traumatic origin. A case report. Acta Neurol (Napoli) 32: 347-353, 1977

9. Halbach VV, Hieshima GB, Higashida RT, Reicher M: Carotid cavernous fistulae: Indications for urgent treatment. Am J Roentgenol 149: 587-593, 1987

10. He HW, Jiang CH, Wu ZX, Li YX, Lu XL, Wang ZC: Transvenous embolization with a combination of detachable coils and Onyx for a complicated cavernous dural arteriovenous fistula. Chin Med J (Engl) 121:1651-1655, 2008

11. Kirsch M, Henkes H, Liebig T, Weber W, Esser J, Golik S, Kühne D: Endovascular management of dural carotid-cavernous sinus fistulas in 141 patients. Neuroradiology 48:486-490, 2006
12. Luo CB, Teng MM, Chang FC, Sheu MH, Guo WY, Chang CY: Bilateral traumatic carotid-cavernous fistulae: Strategies for endovascular treatment. Acta Neurochir 149(7):675-680, 2007

13. Ng SH, Wan YL, Ko SF, Lee ST, Wong HF, Chen YL, Cheung YC: Bilateral traumatic carotid-cavernous fistulas successfully treated by detachable balloon technique. J Trauma 47: 1156-1159, 1999

14. Plasencia AR, Santillan A: Endovascular embolization of carotid-cavernous fistulas: A pioneering experience in Peru. Surg Neurol Int 3:5, 2012

15. Serbinenko FA: Balloon catheterization and occlusion of major cerebral vessels. J Neurosurg 41:125-145, 1974

16. Szkup P, Beningfield S: Endovascular treatment of posttraumatic carotidcavernous fistulae using latex detachable balloons. South African Journal of Radiology 9(1): 4-15, 2005

17. Tenga $\mathrm{MMH}, \mathrm{Changa} \mathrm{CY}$, Chianga JH, Lirnga JF, Luoa CB, Chena SS, Changa FC, Guoa WY: Double-balloon technique for embolization of carotid cavernous fistulas. Am J Neuroradiol 21: 1753-1756, 2000

18. Zaidat OO, Lazzaro MA, Niu T, Hong SH, Fitzsimmons BF, Lynch JR, Sinson GP: Multimodal endovascular therapy of traumatic and spontaneous carotid cavernous fistula using coils, n-BCA, Onyx and stent graft. J Neurointerv Surg 3:255-262, 2011 